\title{
Related party transactions, de tegenstrijdig- belangregeling en het voorkomen van belangen- verstrengeling in de Nederlandse Corporate Governance Code: waar zijn we nu aan toe?
}

\author{
A.C. Jansen
}

\section{Inleiding}

Op 1 december 2019 is de nieuwe regeling voor related party transactions, die de Nederlandse wetgever heeft moeten implementeren naar aanleiding van de herziene Europese Aandeelhoudersrichtlijn, in werking getreden. ${ }^{1}$ De Europese Aandeelhoudersrichtlijn is door de Europese Commissie herzien - en uiteindelijk aangenomen door het Europees Parlement en de Europese Raad - aangezien in de afgelopen jaren bepaalde tekortkomingen in de corporate governance van beursvennootschappen aan het licht zijn gekomen, namelijk onvoldoende betrokkenheid van aandeelhouders en gebrek aan transparantie. Meer in het bijzonder heeft de Europese Commissie vastgesteld dat met name minderheidsaandeelhouders te weinig zicht hebben en toezicht kunnen uitoefenen op related party transactions, oftewel transacties met verbonden partijen waarbij sprake is van (potentiële) belangenverstrengeling. ${ }^{2}$ Dergelijke transacties kunnen nadelig zijn voor beursvennootschappen wanneer deze niet onder marktconforme voorwaarden zijn aangegaan of op een andere wijze bevoordelend zijn voor de wederpartij. Bestuurders, commissarissen en grootaandeelhouders bijvoorbeeld, krijgen bij het aangaan van related party transactions namelijk de mogelijkheid om vermogen aan beursvennootschappen te onttrekken, zonder dat dit voor de andere betrokken stakeholders gemakkelijk zichtbaar wordt. Oneigenlijke vermogensonttrekking leidt tot waardevermindering van de onderneming en daarmee tot verlies van aandeelhouderswaarde, waardoor minderheidsaandeelhouders en institutionele investeerders zullen worden geschaad, maar ook schuldeisers, werknemers

1 Besluit van 25 november 2019 tot vaststelling van het tijdstip van inwerkingtreding van de Wet van 6 november 2019 tot wijziging van Boek 2 van het Burgerlijk Wetboek, de Wet op het financieel toezicht en de Wet giraal effectenverkeer ter uitvoering van Richtlijn 2017/828/EU van het Europees Parlement en de Raad van 17 mei 2017 tot wijziging van Richtlijn 2007/36/EG wat het bevorderen van de langetermijnbetrokkenheid van aandeelhouders betreft (PbEU 2017, L 132), Stb. 2019, 423.

2 Richtlijn 2017/828/EU, preambule 42-44. Zie ook V.O. Ersungur \& J.M. Vermogen, Related party transactions, Bb 2018/53, par. 1. 
en andere belanghebbenden kunnen nadelige gevolgen hiervan ervaren. ${ }^{3}$ De nieuwe regels voor related party transactions hebben dan ook tot doel de vennootschap en met name haar (minderheids)aandeelhouders te beschermen tegen dergelijke transacties met verbonden partijen waarbij sprake is van (potentiële) belangenverstrengeling. ${ }^{4}$

Naast deze nieuwe regeling voor related party transactions kent het Nederlandse vennootschapsrecht alleen nog twee regelingen die toezien op het voorkomen van belangenverstrengeling bij transacties met al dan niet verbonden partijen. In Boek 2 van het Burgerlijk Wetboek (BW) is namelijk de tegenstrijdigbelangregeling opgenomen, op grond waarvan bestuurders en commissarissen met een persoonlijk belang, tegenstrijdig aan het vennootschappelijk belang, niet mogen deelnemen aan beraadslaging en besluitvorming. ${ }^{5}$ Daarnaast schrijft principe 2.7 van de Nederlandse Corporate Governance Code (NCGC) voor dat elke vorm van belangenverstrengeling tussen de vennootschap en haar bestuurders en commissarissen dient te worden vermeden. Voor de komst van de nieuwe regeling voor related party transactions was het al de vraag hoe deze twee bestaande regelingen zich tot elkaar verhielden en bestond onduidelijkheid over hoe met deze regelingen moest worden omgegaan in de praktijk, maar met de komst van een derde nieuwe regeling is deze onduidelijkheid alleen nog maar groter geworden. Waar zijn we nu aan toe?

Deze bijdrage gaat in op de verhouding tussen de nieuwe regeling voor related party transactions enerzijds en de bestaande tegenstrijdigbelangregeling en het voorkomen van belangenverstrengeling in de NCGC anderzijds. Hiertoe beschrijft deze bijdrage eerst de nieuwe regels voor related party transactions (par. 2), gaat de bijdrage vervolgens in op de onderlinge verhoudingen (par. 3) en beantwoordt de bijdrage tot slot de vraag wat de nieuwe regeling voor related party transactions toevoegt en hoe daarmee moet worden omgegaan in de praktijk (par. 4). De bijdrage sluit af met een conclusie en een aanbeveling (par. 5).

\section{De nieuwe regeling voor related party transactions}

De nieuwe regeling voor related party transactions is door de Nederlandse wetgever geïmplementeerd in Boek 2 BW onder afdeling 8 van de nv-titel voor naamloze vennootschappen, te weten art. 2:167-170 BW, en onder afdeling 1 van de bv-titel voor besloten vennootschappen in art. 2:187 BW, een schakelbepaling die onder meer art. 2:167-170 BW voor naamloze vennootschappen van overeen-

3 I.C.P. Groenland, Related party transactions, Ondernemingsrecht 2018/112, par. 2.1. Het op deze manier onttrekken van vermogen aan de vennootschap wordt overigens ook wel 'tunneling' genoemd, waar Winter al in 2001 over schreef, zie J. Winter, Tunneltjes graven, Ondernemingsrecht 2001, p. 217.

4 Richtlijn 2017/828/EU, preambule 42-44.

5 Art. 2:129 lid 6 en 2:139 lid 6 BW voor bestuurders van respectievelijk nv's en bv's en art. 2:140 lid 5 en 2:150 lid 5 BW voor commissarissen van respectievelijk nv's en bv's. 
komstige toepassing op besloten vennootschappen verklaart. ${ }^{6}$ De regeling is van toepassing op beursvennootschappen met een statutaire zetel in een lidstaat van de Europese Unie waarvan de aandelen zijn genoteerd aan een reguliere beurs in de Europese Unie, ${ }^{7}$ en daarnaast dient aan twee cumulatieve voorwaarden te worden voldaan, namelijk dat sprake is van transactie met een verbonden partij en dat de transactie materieel is. ${ }^{8}$ Voor de vraag of sprake is van een verbonden partij verwijst de regeling naar de definitie van een verbonden partij als bedoeld in alinea 9 van de International Accounting Standards (IAS) 24. Deze definitie is een lastig toegankelijke bepaling, maar komt er kort gezegd op neer dat onder een verbonden partij zowel natuurlijke personen als rechtspersonen, alsmede eerstegraads familieleden of echtgenoten en groepsmaatschappijen (inclusief dochtermaatschappijen) van de vennootschap, voor zover deze een belangrijke invloed op de (beurs)vennootschap kunnen uitoefenen, worden verstaan. ${ }^{9}$ Bovendien schrijft de regeling voor dat onder een verbonden partij in ieder geval een of meer houders van aandelen met een gezamenlijk belang van $10 \%$ vallen, maar ook de bestuurders en commissarissen van de beursvennootschap. ${ }^{10}$ Daarnaast is volgens de regeling sprake van een materiële transactie indien de informatie over de transactie voorwetenschap is als bedoeld in art. 7 lid 1 van de Verordening Marktmisbruik. ${ }^{11}$ Dit betekent dat de informatie over de transactie koersgevoelig dient te zijn. Het moet dan gaan om concrete informatie die direct of indirect betrekking heeft op de vennootschap en die, indien de informatie openbaar wordt gemaakt, een significante negatieve invloed zou kunnen hebben op de waarde van de onderneming en/of de hoogte van de beurskoers. ${ }^{12}$ Dit is bijvoorbeeld het geval wanneer de informatie over die transactie ervoor zorgt dat de aandeel-

$6 \quad$ Kamerstukken II 2018/19, 35058, nr. 3, p. 3.

7 Art. 2:167 lid 1 BW.

8 Art. 2:167 lid 2 jo. lid 3 onder b BW respectievelijk art. 2:167 lid 3 onder a BW.

9 Vgl. Ersungur \& Vermogen 2018, par. 3.3 en J.M. de Jongh, Tegenstrijdig belang en transacties met verbonden partijen, Ondernemingsrecht 2019/160, par. 3.1.

10 Art. 2:167 lid 3 onder b BW. De Jongh merkt terecht op dat de wettelijke definitie 'verbonden partijen' zoals hier bedoeld niet identiek is aan de definitie in alinea 9 IAS 24, zie De Jongh 2019, par. 3.1. De Minister van Justitie en Veiligheid (JenV) heeft in de NvT hierover opgemerkt dat wanneer een vennootschap een transactie aangaat, eerst dient te worden getoetst aan het begrip 'verbonden partij' zoals in alinea 9 IAS 24, dan aan het begrip 'voorwetenschap', en pas daarna komt art. 2:167 lid 3 onder b BW aan bod. Het artikel spreekt namelijk over 'in ieder geval', dus ook aandeelhouders met een kleiner belang kunnen onder de nieuwe regeling vallen, omdat ze wel onder het begrip 'verbonden partijen' zoals in alinea 9 IAS 24 vallen, zie Kamerstukken II 2018/19, 35058, nr. 6, p. 7.

11 Verordening EU 596/2014 van het Europees Parlement en de Raad van 16 april 2014 betreffende marktmisbruik (Verordening Marktmisbruik).

12 Art. 7 lid 1 onder a Verordening Marktmisbruik. Zie ook C.R. Nagtegaal \& R.L. Pouwer, Related party transactions: verandert er iets?, TOP 2019, afl. 6, p. 33. Opgemerkt dient te worden dat Hijink en In 't Veld van mening zijn dat de voorwetenschapsdefinitie beperkt moet worden uitgelegd. De voorwetenschapsdefinitie uit de Verordening Marktmisbruik is volgens hen namelijk niet beperkt tot informatie die betrekking heeft op, en invloed kan hebben op, de koers van de beursvennootschap zelf die de transactie met een verbonden partij is aangegaan, maar ook op andere beursvennootschappen, hetgeen niet de bedoeling van de Europese wetgever kan zijn geweest, zie S. Hijink \& L. in 't Veld, Valkuilen bij het bestrijden van tunneltjes, Ondernemingsrecht 2019/84. 
houders van de vennootschap die geen verbonden partij zijn op basis van de informatie besluiten hun aandelen (massaal) te verkopen. ${ }^{13}$

Is sprake van een materiële transactie met een verbonden partij, dan maakt de nieuwe regeling vervolgens een onderscheid tussen twee typen materiële transacties. Ten eerste geldt er een soort 'licht' regime voor materiële transacties die onder marktconforme voorwaarden en in de gewone bedrijfsuitoefening worden aangegaan. ${ }^{14}$ Hiervoor geldt dat de raad van commissarissen $(\mathrm{RvC})$ - of het bestuur indien sprake is van een one tier board - slechts een procedure dient vast te stellen om periodiek te kunnen beoordelen of steeds aan deze twee voorwaarden wordt voldaan. Verbonden partijen nemen uiteraard niet deel aan deze beoordeling. ${ }^{15}$ Daarnaast geldt een 'verzwaard' regime voor transacties die niet marktconform zijn of buiten de normale bedrijfsuitoefening worden aangegaan. Dit 'verzwaarde' regime bestaat uit drie elementen, namelijk een openbaarmakingsverplichting, een goedkeuringsverplichting en het uitsluiten van bestuurders, commissarissen en aandeelhouders van besluitvorming indien deze betrokken zijn bij de materiële transactie met een verbonden partij. Volgens de openbaarmakingsverplichting dienen beursvennootschappen materiële transacties met verbonden partijen voortaan openbaar te maken op het moment dat de transactie is aangegaan. ${ }^{16}$ Hiervoor geldt dat de aankondiging hiervan ten minste de aard van de relatie met de verbonden partij, de naam van de verbonden partij, de datum van de transactie, de waarde van de transactie en andere informatie die noodzakelijk is voor de beoordeling van de transactie die redelijk en billijk is vanuit het oogpunt van de vennootschap en de (minderheids)aandeelhouders, bevat. ${ }^{17}$ Bovendien dient de informatie op zodanige wijze openbaar te worden gemaakt dat deze snel toegankelijk is en volledig, op correcte wijze en tijdig kan worden beoordeeld door het publiek, wat kan plaatsvinden langs elektronische weg via bijvoorbeeld een e-mail of via een bericht op de website van de beursvennootschap. ${ }^{18}$ De goedkeuringsverplichting houdt in dat materiële transacties met verbonden partijen voortaan dienen te worden goedgekeurd door de $\mathrm{RvC}$ - of het bestuur indien sprake is van een one tier board - en onder bepaalde omstandigheden komt deze goedkeuringsbevoegdheid zelfs toe aan de algemene

13 Opvallend is dat het begrip 'transactie' niet is gedefinieerd in de nieuwe regeling. De Minister van JenV heeft dit wel verduidelijkt in de MvT, namelijk dat hieronder 'allerlei soorten' transacties vallen, zie Kamerstukken II 2018/19, 35058, nr. 3, p. 54. Het begrip 'transactie' dient dus ruim te worden uitgelegd en dat past ook bij het doel van de regeling, namelijk dat de beschermende werking van de regeling niet moeten afhangen van de vraag of er sprake is van een transactie of niet, zie Nagtegaal \& Pouwer 2019, p. 33-34.

14 Art. 2:168 BW. De praktische betekenis van dit artikel is beperkt, aangezien dit type materiële transacties zelden in de praktijk voorkomt. Een transactie onder marktconforme voorwaarden in de normale bedrijfsuitoefening zal namelijk zelden koersgevoelige informatie bevatten, zie ook De Jongh 2019, par. 3.1 en A.F.J.A. Leijten, Belangenconflicten met grootaandeelhouders in beursvennootschappen, in: M.L. Lennarts e.a., Ondernemingsrecht in de Lage Landen. Wat kunnen wij van de Belgen leren?, Deventer: Wolters Kluwer 2020, par. 4.

16 Art. 2:169 lid 1 BW.

17 Art. 2:169 lid 2 BW.

18 Richtlijn 2017/828/EU, preambule 44 en Kamerstukken II 2018/19, 35058, nr. 3, p. 57. 
vergadering (AV). ${ }^{19}$ Dit laatste doet zich alleen voor wanneer het vereiste goedkeuringsbesluit niet kan worden genomen door alle commissarissen - of alle bestuurders indien sprake is van een one tier board - omdat deze allemaal onbevoegd zijn om tot besluitvorming over te gaan op basis van de tegenstrijdigbelangregeling, of dat de commissarissen - of bestuurders - allemaal afwezig zijn wegens ontstentenis of belet. ${ }^{20}$ Daarnaast schrijft de nieuwe regeling dus voor dat bestuurders, commissarissen en aandeelhouders die betrokken zijn bij materiële transacties als verbonden partijen, niet meer mogen deelnemen aan de besluitvorming omtrent de transactie. ${ }^{21}$

Tot slot kent de nieuwe regeling voor related party transactions nog een aantal vrijstellingen en twee nadere regels. Transacties tussen de vennootschap en een dochtermaatschappij, met betrekking tot de bezoldiging van bestuurders, met kredietinstellingen en transacties die onder dezelfde voorwaarden aan alle aandeelhouders worden aangeboden, mits de gelijke behandeling van alle aandeelhouders en het vennootschappelijk belang gewaarborgd zijn, zijn namelijk vrijgesteld van de openbaarmakingsverplichting, de goedkeuringsverplichting en de verplichting tot het uitsluiten van bestuurders, commissarissen en aandeelhouders van besluitvorming indien deze betrokken zijn bij de materiële transacties met verbonden partijen (het 'verzwaarde' regime). ${ }^{22}$ Bovendien schrijft de nieuwe regeling nog een aparte openbaarmakingsverplichting voor, wanneer een dochtermaatschappij materiële transacties met verbonden partijen aangaat. ${ }^{23}$ Daarnaast schrijft de nieuwe regeling voor dat transacties die in een periode van twaalf maanden of in hetzelfde boekjaar met dezelfde verbonden partij worden aangegaan, en op zichzelf niet als materieel kwalificeren, toch als materiële transacties moeten worden aangemerkt, wanneer deze transacties in samenhang wel als materiële transacties kwalificeren. ${ }^{24}$

\section{De verhouding tussen de nieuwe regeling voor related party transactions enerzijds en de bestaande tegenstrijdigbelangregeling en het voorkomen van belangenverstrengeling in de NCGC anderzijds}

\subsection{De nieuwe regeling voor related party transactions versus de tegenstrijdigbelangregeling}

De tegenstrijdigbelangregeling is zoals eerder genoemd opgenomen in Boek 2 BW, op grond waarvan bestuurders en commissarissen met een persoonlijk belang,

19 Art. 2:169 lid 3 BW.

20 Groenland 2018, par. 6.3.

21 Art. 2:169 lid 4 BW.

22 Art. 2:169 lid 5 BW.

23 Art. 2:170 BW. Dit artikel schrijft voor dat art. 2:168 BW (het 'lichte' regime) en art. 2:169 lid 1 en 2 BW (de openbaarmakingsverplichting) en art. 2:169 lid 5 BW (vrijstellingen) van toepassing zijn.

24 Art. 2:167 lid 4 BW. In dit geval zullen de transacties wel alsnog openbaar moeten worden gemaakt, maar hoeven de transacties niet alsnog goedgekeurd te worden, zie Kamerstukken II 2018/19, 35058, nr. 3, p. 21. 
tegenstrijdig aan het vennootschappelijk belang, niet mogen deelnemen aan beraadslaging en besluitvorming. ${ }^{25}$ De nieuwe regeling voor related party transactions en de tegenstrijdigbelangregeling kennen dus een ander aangrijpingspunt. Daar waar de nieuwe regeling aangrijpt bij de wederpartij (er dient immers sprake te zijn van een verbonden partij) en de aard van de transactie (de transactie dient materieel te zijn), grijpt de tegenstrijdigbelangregeling aan bij tegenstrijdige belangen van bestuurders en commissarissen. ${ }^{26}$ Dit verschil in aangrijpingspunt zorgt ervoor dat de regelingen - wat hun reikwijdte betreft - deels overlappen, maar in een aantal opzichten gaat met name de nieuwe regeling verder dan de tegenstrijdigbelangregeling.

Het begrip 'verbonden partijen' waarbij de nieuwe regeling voor related party transactions aangrijpt, is ten eerste namelijk aanzienlijk breder dan slechts de bestuurders en commissarissen bij wie de tegenstrijdigbelangregeling aangrijpt. Ook aandeelhouders, niet-statutaire leden van het management met sleutelposities in de beursvennootschap, eerstegraads familieleden en echtgenoten, en zelfs groepsmaatschappijen (waaronder dochtermaatschappijen), mits deze maar invloed van betekenis hebben in de beursvennootschap, vallen onder de nieuwe regeling en niet onder de tegenstrijdigbelangregeling. ${ }^{27}$

Daarnaast zorgt het begrip 'voorwetenschap' waarbij de nieuwe regeling voor related party transactions aangrijpt ervoor dat, in tegenstelling tot de tegenstrijdigbelangregeling, niet alleen persoonlijke belangenconflicten onder de regeling vallen, maar ook belangenconflicten van een andere aard. Is sprake van concrete informatie over een transactie, die direct of indirect betrekking heeft op de beursvennootschap, en zou die informatie, indien openbaar gemaakt, een significante negatieve invloed kunnen hebben op de waarde van de onderneming en/of de hoogte van de beurskoers, dan is namelijk sprake van een materiële transactie en wordt een belangenconflict als het ware verondersteld. ${ }^{28}$ De tegenstrijdigbelangregeling daarentegen grijpt alleen, rechtstreeks, aan bij de persoonlijke belangen van bestuurders en commissarissen, die tegenstrijdig zijn aan het vennootschappelijk belang. ${ }^{29}$ In de meeste gevallen waarin de nieuwe regeling van toepassing is, zal ook de tegenstrijdigbelangregeling van toepassing zijn, aangezien bij materiële transacties met verbonden partijen meestal wel tegenstrijdige belangen van bestuurders en commissarissen spelen, maar voor die gevallen dat er geen tegenstrijdige belangen van bestuurders en commissarissen aanwezig zijn, omdat sprake is van een ander belangenconflict, of het gaat om belangenconflic-

Art. 2:129 lid 6 en 2:139 lid 6 BW voor bestuurders van respectievelijk nv's en bv's en art. 2:140 lid 5 en 2:150 lid 5 BW voor commissarissen van respectievelijk nv's en bv's.

De Jongh 2019, par. 3.1.

Vgl. Groenland 2018, par. 2.2. Zie overigens voor een uitgebreide omschrijving van het begrip 'verbonden partijen' in de nieuwe regeling F. Leijten, Transacties met verbonden partijen (a.k.a. 'transwakkies') een proeve van richtlijnimplementatie, in: H.J. de Kluiver, S. Perrick \& I. Spinath (red.), Kort juridisch. Liber amicorum Peter Wakkie, Deventer: Wolters Kluwer 2018, p. 105-112. De Jongh 2019, par. 3.1.

Art. 2:129 lid 6 en 2:139 lid 6 BW voor bestuurders van respectievelijk nv's en bv's en art. 2:140 lid 5 en 2:150 lid 5 BW voor commissarissen van respectievelijk nv's en bv's. 
ten van andere verbonden partijen, is dus voortaan de nieuwe regeling voor related party transactions van toepassing. Voor de volledigheid dient hierbij te worden opgemerkt dat overigens ook het tegenovergestelde zich kan voordoen, namelijk dat alleen de tegenstrijdigbelangregeling van toepassing is en niet de nieuwe regeling, maar dat is alleen het geval wanneer tegenstrijdige belangen van bestuurders en commissarissen wel spelen, maar het gaat om kleinere, niet-koersgevoelige transacties. ${ }^{30}$

Bovendien zorgt het begrip 'voorwetenschap' waarbij de nieuwe regeling voor related party transactions aangrijpt ervoor dat, in tegenstelling tot de tegenstrijdigbelangregeling, ook potentiële belangenconflicten onder de nieuwe regeling vallen. Het voorwetenschapscriterium toetst namelijk of sprake is van informatie over een transactie die een significante negatieve invloed zou kunnen hebben op de waarde van de onderneming en/of de hoogte van de beurskoers. De woorden 'zou kunnen hebben op' impliceren dat ook indien sprake is van een zekere waarschijnlijkheid dat er sprake is van koersgevoelige informatie, er sprake is van een materiële transactie in de zin van de nieuwe regeling. ${ }^{31}$ Voor de vraag of sprake is van een tegenstrijdig belang in de zin van de tegenstrijdigbelangregeling daarentegen, dient de zogenaamde 'Bruil'-toets te worden toegepast, op grond waarvan beoordeeld dient te worden of sprake is van een direct of indirect persoonlijk belang, tegenstrijdig aan het vennootschappelijk belang, hetgeen een integere en onbevooroordeelde belangenbehartiging in de weg staat, met inachtneming van alle relevante omstandigheden van het concrete geval. ${ }^{32}$ Deze materiële benadering brengt met zich dat de tegenstrijdigbelangregeling dus alleen van toepassing is indien daadwerkelijk sprake is van een tegenstrijdig belang, en dat de enkele omstandigheid dat een bestuurder of commissaris een tegenstrijdig belang heeft, niet automatisch hoeft te leiden tot de kwalificatie van een tegenstrijdig belang. ${ }^{33}$ De nieuwe regeling voor related party transactions voorkomt dus wel de schijn van, of potentiële belangenverstrengeling en de tegenstrijdigbelangregeling niet.

Naast dat beide regelingen een ander aangrijpingspunt kennen, en daarmee met name de nieuwe regeling verder gaat dan de tegenstrijdigbelangregeling, kennen de regelingen tot slot ook andere verplichtingen wanneer ze van toepassing zijn. De verplichting dat transacties die onder marktconforme voorwaarden en in het kader van de bedrijfsuitoefening worden aangegaan periodiek moeten worden beoordeeld door de $\mathrm{RvC}$ of steeds aan deze twee voorwaarden wordt voldaan, en de openbaarmakingsverplichting en de goedkeuringsverplichting voor transacties die niet onder marktconforme voorwaarden of buiten het kader van de normale bedrijfsuitoefening worden aangegaan, kent de tegenstrijdigbelangregeling namelijk niet. De verplichting dat bestuurders, commissarissen en aandeel-

30 Vgl. De Jongh 2019, par. 3.3 en Nagtegaal \& Pouwer 2019, p. 35.

31 Zie voor meer over het voorwetenschapscriterium D.R. Doorenbos, Openbaarmaking van voorwetenschap onder de Verordening marktmisbruik, Ondernemingsrecht 2016/83.

32 HR 29 juni 2007, ECLI:NL:HR:2007:BA0033, NJ 2007/420 (Bruil), r.o. 3.4.

33 Kamerstukken II 2008/09, 31763, nr. 3, p. 12 en 18. 
houders dienen te worden uitgesloten van besluitvorming indien ze betrokken zijn bij materiële transacties met een verbonden partij, mits de transacties niet onder marktconforme voorwaarden of buiten het kader van de normale bedrijfsuitoefening zijn aangegaan, kent de tegenstrijdigbelangregeling daarentegen wel. De tegenstrijdigbelangregeling is namelijk een besluitvormingsregeling op grond waarvan bestuurders en commissarissen met een tegenstrijdig belang niet mogen deelnemen aan beraadslaging en besluitvorming. Hiermee gaat de tegenstrijdigbelangregeling verder dan de nieuwe regeling, aangezien het voor de tegenstrijdigbelangregeling ten eerste niet uitmaakt of transacties al dan niet onder marktconforme voorwaarden, dan wel in of buiten het kader van de normale bedrijfsuitoefening worden aangegaan. Ten tweede schrijft de tegenstrijdigbelangregeling, in tegenstelling tot de nieuwe regeling, voor dat bestuurders en commissarissen niet mogen deelnemen aan zowel de beraadslaging als de besluitvorming. Dit betekent dat bestuurders en commissarissen zowel niet mogen deelnemen aan de voorbereiding van een besluit als aan de uiteindelijke stemming daarover en dat vanaf het moment dat een onderwerp voor discussie en gedachtevorming in vergaderingen wordt opengesteld, bestuurders en commissarissen met tegenstrijdige belangen niet langer tijdens de vergadering aanwezig mogen zijn. ${ }^{34}$ Aangezien de nieuwe regeling alleen spreekt over het uitsluiten van de besluitvorming lijkt het erop dat bestuurders, commissarissen en aandeelhouders onder de verplichting van de nieuwe regeling wel mogen deelnemen aan de voorbereiding van een besluit, en dat pas vanaf het moment dat een onderwerp ter stemming in de vergadering wordt opengesteld, bestuurders, commissarissen en aandeelhouders betrokken bij materiële transacties met verbonden partijen niet langer tijdens de vergadering aanwezig mogen zijn. ${ }^{35}$ Desalniettemin gaat de nieuwe regeling voor related party transactions op haar beurt weer verder dan de tegenstrijdigbelangregeling, aangezien ook aandeelhouders onder de verplichting vallen, en bovendien mogen bestuurders en commissarissen met andere belangenconflicten dan een tegenstrijdig belang ook niet deelnemen aan besluitvorming wanneer ze betrokken zijn bij materiële transacties met een verbonden partij en deze transacties niet onder marktconforme voorwaarden of buiten het kader van de normale bedrijfsuitoefening zijn aangegaan.

\subsection{De nieuwe regeling voor related party transactions versus het voorkomen van belangenverstrengeling in de NCGC}

Net zoals de tegenstrijdigbelangregeling in vergelijking met de nieuwe regeling voor related party transactions, kent principe 2.7 van de NCGC, dat voorschrijft dat elke vorm van belangenverstrengeling tussen de vennootschap en haar bestuurders, commissarissen en eigenlijk ook haar grootaandeelhouders dient te naar art. 2:129 lid 6, tweede en derde volzin, en 2:140 lid 5, tweede en derde volzin, BW. Dit betekent dat de regels van de tegenstrijdigbelangregeling met betrekking tot aan wie de besluitvormingsbevoegdheid toekomt wanneer besluiten van de beursvennootschap niet kunnen worden genomen, omdat alle bestuurders of alle commissarissen wegens de verplichting niet mogen deelnemen aan de besluitvorming, van overeenkomstige toepassing zijn. 
worden vermeden, ook een ander aangrijpingspunt. ${ }^{36}$ Dit verschil in aangrijpingspunt zorgt ervoor dat ook hier geldt dat de nieuwe regeling en de NCGC overlappen, maar in de meeste opzichten gaat de nieuwe regeling verder dan de NCGC.

Het begrip 'verbonden partijen' waarbij de nieuwe regeling aangrijpt, is ten eerste namelijk nog steeds aanzienlijk breder dan het vermijden van belangenverstrengeling van bestuurders, commissarissen én grootaandeelhouders, waarbij de NCGC aangrijpt. De NCGC gaat hiermee wel verder dan de tegenstrijdigbelangregeling, aangezien grootaandeelhouders dus wel onder de NCGC vallen. Voor de vraag of sprake is van een grootaandeelhouder sluiten de nieuwe regeling en de NCGC overigens bij elkaar aan, want volgens best practice bepaling 2.7.5 is sprake van een grootaandeelhouder indien sprake is van een natuurlijke of rechtspersoon die ten minste $10 \%$ van de aandelen in de vennootschap houdt, en volgens de nieuwe regeling voor related party transactions is sprake van een grootaandeelhouder indien een of meer houders van aandelen, alleen of gezamenlijk, ten minste een tiende gedeelte van het geplaatste kapitaal vertegenwoordigen. ${ }^{37}$

Wat wel overlapt is dat de NCGC, net zoals de nieuwe regeling voor related party transactions, maar in tegenstelling tot de tegenstrijdigbelangregeling, een aantal best practice bepalingen voorschrijft die toezien op het vermijden van belangenverstrengeling in het algemeen en niet alleen toezien op het vermijden van belangenverstrengeling van persoonlijke aard. Best practice bepaling 2.7.1 schrijft namelijk voor dat bestuurders en commissarissen alert dienen te zijn op - de overkoepelende term - belangenverstrengeling, waarbij vervolgens een aantal situaties wordt genoemd die bestuurders en commissarissen ten opzichte van de beursvennootschap in ieder geval niet mogen doen, en daarnaast schrijft best practice bepaling 2.7.2 voor dat het reglement van de $\mathrm{RvC}$ regels dient te bevatten voor de wijze waarop met belangenverstrengeling dient te worden omgegaan. ${ }^{38}$ De situaties genoemd in best practice bepaling 2.7.1 zullen in de meeste gevallen overigens leiden tot voorwetenschap, waardoor naast de NCGC ook de nieuwe regeling voor related party transactions van toepassing is, maar het kan ook voorkomen dat de genoemde situaties niet leiden tot voorwetenschap, en dan zijn alleen de betreffende best practice bepalingen van de NCGC van toepassing.

36 Principe 2.7 van de NCGC spreekt in eerste instantie over het voorkomen van belangenverstrengeling van bestuurders en commissarissen, maar in principe 2.7, laatste volzin, wordt ook gesproken over belangenverstrengeling bij grootaandeelhouders. Bovendien schrijft best practice bepaling 2.7.5 een gedragsnorm voor transacties tussen de beursvennootschap en haar grootaandeelhouders voor. Grootaandeelhouders vallen dus ook onder de NCGC.

37 Best practice bepaling 2.7.5 van de NCGC in vergelijking met art. 2:167 lid 3 onder b BW.

38 Zo mogen bestuurders en commissarissen in ieder geval niet in concurrentie met de vennootschap treden, geen (substantiële) schenkingen van de vennootschap voor zichzelf of voor eersteof tweedegraads familieleden aannemen, ten laste van de vennootschap geen ongerechtvaardigde voordelen verschaffen aan derden en geen zakelijke kansen die aan de vennootschap toekomen, benutten voor zichzelf of voor eerste- of tweedegraads familieleden, zie best practice bepaling 2.7.1. Hiermee gaat de NCGC overigens verder dan de nieuwe regeling voor related party transactions, aangezien onder het begrip 'verbonden partijen' alleen eerstegraads familieleden worden verstaan. 
In de volgende best practice bepalingen gaat de NCGC, net zoals de tegenstrijdigbelangregeling, vervolgens alleen nog maar in op tegenstrijdige belangen van bestuurders, commissarissen en grootaandeelhouders van persoonlijke aard. ${ }^{39}$ Voor de vraag of sprake is van dergelijke tegenstrijdige belangen van persoonlijke aard lijkt de NCGC volledig aan te sluiten bij de tegenstrijdigbelangregeling. Best practice bepaling 2.7.3 gaat namelijk specifiek in op het begrip tegenstrijdig belang door een aantal voorbeelden te geven die kunnen kwalificeren als een tegenstrijdig belang, waarbij het kunnen kwalificeren als een tegenstrijdig belang impliceert dat ook de NCGC niet automatisch uitgaat van de aanwezigheid van tegenstrijdige belangen van persoonlijke aard. ${ }^{40}$ Andere aanwijzingen zijn dat uit principe 2.7 van de NCGC het woord 'schijn' is geschrapt en dat in best practice bepaling 2.7.3 het zogenaamde 'kwalitatief tegenstrijdig belang' niet langer meer als voorbeeld van een tegenstrijdig belang voorkomt. ${ }^{41}$ Bovendien heeft de Hoge Raad uiteindelijk in het Versatel-arrest bevestigd dat voor de vraag of sprake is van tegenstrijdige belangen van persoonlijke aard in de zin van de NCGC, dient te worden aangesloten bij de 'Bruil'-toets van de tegenstrijdigbelangregeling. ${ }^{42}$ Hieruit volgt dat volgens de NCGC dus ook alleen sprake is van tegenstrijdige belangen van persoonlijke aard, indien sprake is van daadwerkelijke tegenstrijdige belangen van persoonlijke aard, en dat de enkele schijn van, of potentiële, tegenstrijdige belangen van persoonlijke aard niet met de NCGC worden vermeden. Al met al kan dus worden vastgesteld dat, net zoals ten opzichte van de tegenstrijdigbelangregeling, de nieuwe regeling voor related party transactions verder gaat dan de NCGC, aangezien met de nieuwe regeling wel de schijn van of de potentiële belangenverstrengeling wordt vermeden en bovendien onder de nieuwe regeling niet alleen belangenverstrengeling van persoonlijke aard valt, maar belangenverstrengeling in het algemeen.

Tot slot geldt ook hier dat, naast dat de nieuwe regeling voor related party transactions en de NCGC een ander aangrijpingspunt kennen en daarmee de nieuwe regeling verder dan de NCGC gaat, de regelingen andere verplichtingen kennen wanneer ze van toepassing zijn. Ondanks dat de NCGC een gedragscode is waarin de best practice bepalingen allemaal gedragsnormen voorschrijven waar-

39 Zie best practice bepaling $2.7 .3 \mathrm{t} / \mathrm{m}$ 2.7.6 van de NCGC.

40 In de vorige versies van de NCGC werd nog gesproken over een 'tegenstrijdig belang bestaat', wat laat zien dat de NCGC destijds nog wel uitging van de automatische aanwezigheid van een tegenstrijdig belang van persoonlijke aard, zie principe II.3.2 voor bestuurders en principe III.6.1 voor commissarissen van de NCGC 2008.

41 Principe II.3 voor bestuurders en principe III. 6 voor commissarissen van de NCGC 2008 spraken nog over 'elke vorm en schijn van belangenverstrengeling tussen vennootschap en bestuurders (en commissarissen) wordt vermeden'. Bovendien werd in best practice bepaling II.3.2.iii voor bestuurders en best practice bepaling III.6.1.iii voor commissarissen van de NCGC 2008 nog als voorbeeld het kwalitatief tegenstrijdig belang genoemd: 'Een tegenstrijdig belang bestaat in ieder geval wanneer de vennootschap voornemens is een transactie aan te gaan met een rechtspersoon: (iii) waarbij een bestuurder (of een commissaris) van de vennootschap een bestuurs- of toezichthoudende functie vervult.'

42 HR 14 september 2007, ECLI:NL:HR:2007:BA4887, JOR 2007/239, m.nt. Bartman (Versatel), r.o. 4.3 . 
van de nieuwe regeling voor related party transactions de meeste niet kent, vormt de nieuwe regeling toch een aanscherping van de NCGC. Ten eerste kent de NCGC, net zoals de tegenstrijdigbelangregeling, de verplichting dat transacties die onder marktconforme voorwaarden en in het kader van de bedrijfsuitoefening worden aangegaan periodiek moeten worden beoordeeld door de RvC, of steeds aan deze twee voorwaarden wordt voldaan, niet. Ook kent de NCGC, en dit juist in tegenstelling tot de tegenstrijdigbelangregeling, de verplichting dat bestuurders, commissarissen en aandeelhouders dienen te worden uitgesloten van besluitvorming indien ze betrokken zijn bij materiële transacties met verbonden partijen, en de transacties niet onder marktconforme voorwaarden of buiten het kader van de normale bedrijfsuitoefening zijn aangegaan, niet. De verplichtingen die de NCGC daarentegen wel kent, en dat is juist weer in tegenstelling met de tegenstrijdigbelangregeling, zijn een openbaarmakingsverplichting en een goedkeuringsverplichting. Deze verplichtingen worden voorgeschreven in best practice bepaling 2.7.4, die toeziet op transacties tussen de vennootschap en haar bestuurders en commissarissen, en best practice bepaling 2.7.5, die toeziet op transacties tussen de vennootschap en haar grootaandeelhouders, en houden in dat alle transacties waarbij tegenstrijdige belangen van bestuurders, commissarissen en grootaandeelhouders spelen, dienen te worden goedgekeurd door de $\mathrm{RvC}$ en te worden gepubliceerd in het bestuursverslag. Hiermee gaat de NCGC verder dan de nieuwe regeling, aangezien het voor de NCGC niet uitmaakt of transacties al dan niet onder marktconforme voorwaarden, dan wel in of buiten het kader van de normale bedrijfsuitoefening worden aangegaan, want alle transacties dienen te worden goedgekeurd en te worden gepubliceerd in het jaarverslag. Desalniettemin gaat de nieuwe regeling op haar beurt weer verder dan de NCGC, aangezien de nieuwe regeling ten eerste aan de goedkeuringsverplichting toevoegt dat - ondanks dat deze situatie overigens niet snel zal voorkomen wanneer alle leden van de $\mathrm{RvC}$ betrokken zijn bij materiële transacties met een verbonden partij, het goedkeuringsbesluit dient te worden genomen door de AV. Bovendien gaat de nieuwe regeling met haar openbaarmakingsverplichting verder dan de openbaarmakingsverplichting in de NCGC, aangezien volgens de NCGC openbaarmaking pas achteraf in het bestuursverslag dient te geschieden, terwijl de nieuwe regeling voor related party transactions voorschrijft dat openbaarmaking al dient te geschieden op het moment dat de transactie is aangegaan. ${ }^{43}$

\section{Wat voegt de nieuwe regeling voor related party transactions toe en hoe moet daar in de praktijk mee worden omgegaan?}

De nieuwe regeling voor related party transactions heeft een bredere reikwijdte dan de Nederlandse wetgeving tot nu toe heeft gekend om belangenverstrengeling bij beursvennootschappen te voorkomen. Daar waar de Nederlandse wetgever ten eerste weinig oog heeft gehad voor de mogelijkheid dat de feitelijke macht in beursvennootschappen kan liggen bij (groot)aandeelhouders, 
managers met sleutelfuncties in de beursvennootschap die geen statutaire functie hebben en daarmee niet in het bestuur of de $\mathrm{RvC}$ zijn vertegenwoordigd, of andere partijen die invloed van betekenis hebben in de beursvennootschap, en daarmee het risico op belangenverstrengeling zich ook buiten de wettelijke kaders van de tegenstrijdigbelangregeling en de NCGC kan voordoen, vallen deze partijen voortaan onder de nieuwe regeling voor related party transactions. ${ }^{44}$

Ten tweede zorgt de nieuwe regeling voor related party transactions ervoor dat, gezien haar aangrijpingspunt bij het begrip 'voorwetenschap' in plaats van het begrip 'tegenstrijdig belang', voortaan niet alleen belangenverstrengeling van persoonlijke aard bij beursvennootschappen kan worden voorkomen, maar belangenverstrengeling in het algemeen, en zelfs potentiële belangenverstrengeling. Bovendien is 'voorwetenschap' makkelijker vast te stellen dan een 'tegenstrijdig belang', zodat belangenverstrengeling met de nieuwe regeling ook veel effectiever kan worden voorkomen. Ten eerste hoeft namelijk niet meer alleen in de hoofden van bestuurders en commissarissen te worden gekeken of persoonlijke belangen spelen, want is sprake van voorwetenschap, dan wordt onder de nieuwe regeling belangenverstrengeling verondersteld. Ten tweede is de 'Bruil'-toets - in de literatuur fel bekritiseerd - een ex post-toets, op grond waarvan eigenlijk pas achteraf kan worden beoordeeld of sprake is van een tegenstrijdig belang. ${ }^{45}$ Vooraf is het natuurlijk moeilijk in te schatten of persoonlijke belangen van bestuurders en commissarissen daadwerkelijk tegenstrijdig zijn aan het vennootschappelijk belang, en dat terwijl het doel van de tegenstrijdigbelangregeling en de NCGC juist is de vennootschap te beschermen tegen het risico dat bestuurders en commissarissen zich bij hun handelen meer gelegen laten liggen aan persoonlijke belangen dan aan het vennootschappelijk belang. Hiervoor geldt, en dat geldt ook voor belangenverstrengeling in het algemeen, dat voorkomen beter is dan genezen en daarom zou voor een effectieve werking van een regeling die toeziet op het voorkomen van belangenverstrengeling juist bescherming dienen te worden gezocht bij ex ante werkende regels, of in ieder geval regels die vooraf makkelijk toetsbaar zijn. ${ }^{46}$ Het aangrijpingspunt van de nieuwe regeling voor related party transactions bij het begrip 'voorwetenschap', op grond waarvan dient te worden getoetst of informatie over een transactie waarschijnlijk een significante negatieve

44 Met name grootaandeelhouders krijgen de afgelopen jaren veel aandacht, omdat zij vaak toch de kans krijgen hun wil door te drukken wanneer het aankomt op besluitvorming voor de vennootschap. De Ondernemingskamer heeft de afgelopen jaren dan ook in een aantal gevallen toch ingegrepen, ondanks dat de tegenstrijdigbelangregeling of de NCGC van toepassing was. Voorbeelden hiervan zijn: Hof Amsterdam (OK) 24 april 2017, ECLI:NL:GHAMS:2017:1626, JOR 2017/163 (Fortuna/Forbet), Hof Amsterdam (OK) 22 december 2017, ECLI:NL:GHAMS: 2017:5354, RN 2018/12 (Intergamma) en Hof Amsterdam (OK) 31 augustus 2017, ECLI:NL:GHAMS:2017:3532, JOR 2018/41, m.nt. Leijten (Staphort Ontwikkeling). Vgl. De Jongh 2019, par. 3.1 en Groenland 2018, par. 2.2.

45 Zie ook A.F.M. Dorresteijn, Tegenstrijdig belang: het paard achter de wagen, WPNR 2010, afl. 6836, p. 225.

46 Zie ook A.F.M. Dorresteijn, De nieuwe tegenstrijdigbelangregeling en de praktijk, O\&F (18) 2010, afl. 2, p. 114. 
invloed zou kunnen hebben op de waarde van de onderneming en/of de hoogte van de beurskoers, is dan een stap in de juiste richting.

Wanneer de nieuwe regeling voor related party transactions vervolgens van toepassing is, dan zijn de verplichtingen van de nieuwe regeling, en dat geldt ook voor de tegenstrijdigbelangregeling en de NCGC, alleen eigenlijk niet geschikt om belangenverstrengeling effectief te voorkomen, en daarmee voegt de nieuwe regeling in feite weinig toe. De verplichting dat transacties die onder marktconforme voorwaarden en in het kader van de bedrijfsuitoefening steeds door de $\mathrm{RvC}$ moeten worden beoordeeld of aan deze twee voorwaarden wordt voldaan, en de openbaarmakingsverplichting en de goedkeuringsverplichting voor transacties die niet onder marktconforme voorwaarden of in het kader van de bedrijfsuitoefening worden aangegaan, zorgen er weliswaar voor dat beursvennootschappen meer alert zullen - en zullen moeten - zijn op belangenverstrengeling, en bovendien zal belangenverstrengeling ook eerder aan het licht komen, zodat de betrokken stakeholders, en met name de (minderheids)aandeelhouders waarvoor de nieuwe regeling grotendeels is bedoeld, daar beter op kunnen anticiperen, maar feit blijft dat bestuurders, commissarissen, (groot)aandeelhouders en andere partijen met invloed van betekenis beursvennootschappen middels belangenverstrengeling nog steeds kunnen blijven beïnvloeden. De nieuwe regeling voor related party transactions, en daarin gaat de nieuwe regeling zelfs minder ver dan de tegenstrijdigbelangregeling en de NCGC, schrijft namelijk alleen maar voor dat bestuurders, commissarissen en aandeelhouders die betrokken zijn bij materiële transacties met verbonden partijen niet mogen deelnemen aan de besluitvorming, en zoals eerder vastgesteld, betekent dit dat bestuurders, commissarissen en aandeelhouders zich pas hoeven te onttrekken aan de besluitvorming vanaf het moment dat transacties al zodanig zijn uitgekristalliseerd en alleen nog maar ter vergadering moet worden gestemd. Hiermee wordt over het hoofd gezien dat bestuurders, commissarissen, aandeelhouders en overigens ook andere partijen met invloed (denk met name aan managers met sleutelfuncties) allang de mogelijkheid hebben gehad om de uiteindelijke besluitvorming ter vergadering middels belangenverstrengeling te beïnvloeden. Daar komt nog bij dat bij veel transacties, bijvoorbeeld overnames, aan het besluitvormingsproces een heel onderhandelingsproces voorafgaat, waar deze partijen wel gewoon aan mogen deelnemen. Al met al zorgt de nieuwe regeling voor related party transactions er dus wel voor dat, gezien haar bredere reikwijdte, veel meer 'soorten' belangenverstrengeling van verschillende partijen onder de regeling vallen, maar feit blijft dat de verplichtingen die de nieuwe regeling vervolgens met zich brengt niet geschikt zijn om ook effectief belangenverstrengeling bij (beurs)vennootschappen te voorkomen.

Hoe moet hier dan mee worden omgegaan in de praktijk? In de Verenigde Staten is het gebruik van een speciale 'transactiecommissie' een gemeengoed geworden om belangenverstrengeling bij gevoelige transacties tegen te gaan, en dat zal ook 
uitkomst bieden voor de Nederlandse praktijk. ${ }^{47}$ Het gebruik van een speciale transactiecommissie is ontstaan in de rechtspraak omtrent bestuurdersaansprakelijkheid, omdat bestuurders in de Verenigde Staten op zoek waren naar een manier om onder de strenge 'entire fairness-toets' voor bestuurdersaansprakelijkheid uit te kunnen komen. ${ }^{48}$ Wanneer gebruik wordt gemaakt van een speciale transactiecommissie, dan levert dat een belangrijk bewijs op van 'fair dealing', of met andere woorden dat sprake is geweest van een behoorlijk transactie- en besluitvormingsproces, en kunnen bestuurders in de Verenigde Staten inderdaad onder de strenge toets voor bestuurdersaansprakelijkheid uit komen. ${ }^{49}$ Op het moment dat een (beurs)vennootschap voornemens is een transactie aan te gaan, dient namelijk zo snel mogelijk een transactiecommissie te worden opgericht die specifiek is belast met de transactie, en waaraan alleen 'both disinterested and independent members' mogen deelnemen. ${ }^{50}$ Van een 'disinterested member' is volgens het recht van de Verenigde Staten sprake indien deze geen persoonlijk tegenstrijdig belang heeft bij de uitkomst van de transactie, en van een 'independent member' is sprake wanneer de uiteindelijke besluitvorming van de desbetreffende partij alleen is gebaseerd op zakelijke overwegingen en niet kan worden beïnvloed door externe overwegingen of invloeden van andere partijen. ${ }^{51} \mathrm{Dit}$ wordt beoordeeld volgens de zogenaamde 'materiality-standaard', op grond waarvan rechters beoordelen of commissieleden materiële banden hebben met verbonden partijen die ervoor kunnen zorgen dat zij hun taken niet meer onafhankelijk kunnen uitoefenen. ${ }^{52}$ In wezen komt dit ook overeen met de nieuwe regeling voor related party transactions, waarbij in de Verenigde Staten dus niet alleen materieel wordt getoetst of sprake is van belangenverstrengeling (in de nieuwe regeling voor related party transactions het voorwetenschapscriterium), maar ook formeel wordt gekeken welke positie de commissieleden hebben tot verbonden partijen (in de nieuwe regeling voor related party transactions het criterium of sprake is van een verbonden partij), alleen zorgt de verplichting dat meteen bij het aangaan van een transactie een speciale transactiecommissie dient te worden opgesteld er dan voor dat (beurs)vennootschappen gedwongen worden vooraf vast te stellen bij welke partijen belangenverstrengeling speelt, of kan spelen, en krijgen bestuurders, commissarissen en managers met sleutelfuncties niet meer de kans om zowel het onderhandelingsproces als het gehele besluitvormingsproces te beïnvloeden, aangezien zij dan geen deel mogen uitmaken van de transactiecommissie. Hierdoor kan in de Nederlandse praktijk belangenverstrengeling

47 P.L. Hezer, Het special committee naar Amerikaans model bij openbare biedingen, MvO 2017, afl. 10-11, p. 266-275. Het gebruik van een transactiecommissie is ontstaan in de rechtspraak omtrent bestuurdersaansprakelijkheid, zie voor meer hierover S.V. Simpson \& K. Brody, The evolving role of special committee in M\&A transactions, The Business Laywer (69) 2014, afl. 2, p. 1135-1137.

48 Zie Simpson \& Brody 2014, p. 1135-1137.

49 Zie ook Hezer 2017, p. 268.

50 MFW S'holders Litig., 67 A.3d 499-500, 507-510 (Del. Ch. 2013); S. Peru Copper Corp. S'holder Derivative Litig., 52 A.3d 763, 764, 769, 773, 774, 810, 793-797 (Del. Ch. 2011).

51 Aronson v. Lewis, 473 A.2d 805 (Del. 1984).

52 MFW S’holders Litig., 67 A.3ad 510-514 (Del. Ch. 2013). 
ook veel effectiever worden voorkomen, en bovendien kunnen bestuurders, commissarissen en andere partijen met invloed van betekenis in de vennootschap niet achteraf worden geconfronteerd met (bestuurders)aansprakelijkheid.

\section{Conclusie en aanbeveling}

De nieuwe regeling voor related party transactions kent een (veel) bredere reikwijdte dan de tegenstrijdigbelangregeling en de NCGC, zodat in dat opzicht belangenverstrengeling bij beursvennootschappen met de komst van de nieuwe regeling beter kan worden voorkomen, maar net zoals voor de tegenstrijdigbelangregeling en de NCGC geldt, is de nieuwe regeling nog steeds niet geschikt om belangenverstrengeling bij (beurs)vennootschappen effectief tegen te gaan. Het gebruik van een speciale transactiecommissie zal ervoor zorgen dat belangenverstrengeling bij beursvennootschappen wel veel effectiever kan worden tegengegaan, en bovendien dat bestuurders, commissarissen en managers met sleutelfuncties niet achteraf kunnen worden geconfronteerd met (bestuurders)aansprakelijkheid. Het is de Nederlandse wetgever dan ook aan te bevelen om het gebruik van een speciale transactiecommissie zoals in de Verenigde Staten verplicht te stellen, en deze verplichting, wellicht, toe te voegen aan de nieuwe regeling voor related party transactions. 